\title{
Acute mastoiditis, a severe complication of acute otitis media in children - prevalence, diagnosis and treatment
}

\author{
AGATA KAŁUŻNA-MŁYNARCZYK ${ }^{A-F}$, BEATA PUCHER R, D, E, NEL NURCZYK ${ }^{A-D}$, \\ PAULINA ADAMCZYK ${ }^{B}$, MAGDALENA PRAUZIŃSKA ${ }^{B}$, MICHAŁ KOTOWSKI $^{B}$, \\ JAROSŁAW SZYDŁOWSKIA, D
}

\author{
Pediatric Otolaryngology Department, Poznan University of Medical Sciences, Poland
}

A - Study Design, B - Data Collection, C - Statistical Analysis, D - Data Interpretation, E - Manuscript Preparation, F - Literature Search, G - Funds Collection

Summary Background. Acute otitis media in children is one of the most common causes of patients reporting to the family doctor and pediatrician. In rare cases, the inflammatory process spreads deeper into the temporal bone despite proper treatment, resulting in mastoiditis.

Objectives. The aim of this article is to present the most common complication of inflammation of the middle ear. This is mastoiditis. The authors describe mastoiditis by means of its characteristics, the most common symptoms, incidence and treatment.

Material and methods. Data about the patients hospitalized in the Pediatric Otolaryngology Department of the Poznan University of Medical Sciences from January 2017 to April 2018 was analyzed and subjected to a retrospective study. Statistical analysis of the results was performed.

Results. Based on the analyzed medical documentation, the incidence of mastoiditis was evaluated. In addition, the parameters characterizing the diagnostic procedure, along with the treatment methods and the effectiveness of the applied therapies in the hospital conditions, were assessed. The number of outpatient ambulatory visits and the frequency of necessary hospitalizations for patients with uncomplicated otitis media were additionally subjected to evaluation.

Conclusions. The number of cases of inflammation of the middle ear requiring hospitalization in the Pediatric Otolaryngology Department Poznan University of Medical Sciences is minimal, although the complications may present severe health consequences. Uncomplicated acute otitis media may be successfully treated in ambulatory conditions by family physicians and pediatricians. Early detection of the potential complication is essential in the practice of the family doctor.

Key words: mastoiditis, otitis media, child, ear diseases.

Kałużna-Młynarczyk A, Pucher B, Nurczyk N, Adamczyk P, Prauzińska M, Kotowski M, Szydłowski J. Acute mastoiditis, a severe complication of acute otitis media in children - prevalence, diagnosis and treatment. Fam Med Prim Care Rev 2018; 20(3): 227-231, doi: https:// doi.org/10.5114/fmpcr.2018.78256.

\section{Background}

Acute otitis media in children is one of the most common causes of patients reporting to the family doctor and pediatrician, both of whom can successfully treat ear infections [1]. The basic mechanism for the development of acute otitis media (AOM) is dysfunction of the Eustachian tube and impaired ventilation of the tympanic cavity. The principle of conservative treatment is the restoration of Eustachian tube function and symptomatic treatment of earache and fever. In some cases, bacterial infection occurs and patients require systemic antibiotics. Streptococcus pneumoniae is the most frequent bacteria causing acute inflammation of the middle ear. The use of vaccinations against this pathogen reduces the risk of episodes of AOM in children.

In rare cases, the inflammatory process spreads deeper into the temporal bone despite proper treatment. Acute mastoiditis is the result of an acute inflammation of the middle ear that spreads to the pneumatic cells and the mastoid bone [2]. It often leads to periosteitis and osteomyelitis of the temporal bone. The most common cause of mastoiditis is a communication disorder between the tympanic cavity, the mastoid process and the Eustachian tube. The spreading inflammatory process may result in the formation of a subperiosteal abscess and osteolysis of the mastoid bone. Other, less frequent complications are divided into two groups: intratemporal (facial nerve paresis, labyrinthitis) and intracranial (sinus vein thrombosis, meningitis and cerebral abscesses). In addition, a subperiosteal abscess and a much less frequent abscess of Bezold (spreading to the deep neck tissues along the sternocleidomastoid muscle) may be formed. The primary treatment for complications is systemic antibiotic therapy in combination with surgical management. The basic surgical treatment is myringotomy (tympanic membrane incision, paracentesis). This treatment causes decompression of the tympanic cavity and improve access of air to the inside. The procedure can be extended with placement of a ventilation tube which maintains the patency of the incision and ventilation of the middle ear. In more severe cases, surgical treatment is external opening and drainage of the mastoid cavity - the procedure deemed antromasteidectomy.

Although the incidence of severe complications is low, otogenic complications may pose a serious threat to health and life of children [3-5]. Mastoiditis most often affects children up to 2 years old and occurs with a frequency of 1.2-6 per 100,000 cases [6].

\section{Objectives}

The aim of the present study was to determine the frequency of mastoiditis occurrence in children with acute otitis media 
who were admitted to the Pediatric Otolaryngology Department during the last 16 months. Our study included all children treated for otitis media and mastoiditis.

\section{Material and methods}

\section{Study design, setting and participants}

A retrospective study was carried out on patients hospitalized from January 2017 to April 2018 at the Pediatric Otolaryngology Department of Poznan University of Medical Sciences (PUMS). A group of children who reported to the emergency room because of AOM in the same period of time was also analyzed. All patients subjected to the study are patients under 18 years of age. The approval from the Ethics Committee was not required for this research (retrospective analysis).

\section{Data sources}

The incidence of the most frequent otogenic complication was assessed, based on the analysis of the medical documentation of patients from the last 16 months. Moreover, the parameters characterizing the diagnostic procedure with the methods of treatment and the effectiveness of the applied therapies were subjected to evaluation.

\section{Statistical methods}

Statistical analysis of the results was performed. In the studied populations, normal distribution at $\alpha=0.05$ was not proved by both the Shapiro-Wilk and Kolmogorov-Smirnov tests. Chi-squared test and Mann-Whitney $\mathrm{U}$ test were used in the study.

\section{Results}

The results of the retrospective study analysis concluded that for 1520 patients diagnosed with AOM who reported to the emergency room (ER) of the hospital, only 58 patients $(3.68 \%)$ required hospitalization in the Pediatric Otolaryngology Department (Figure 1).

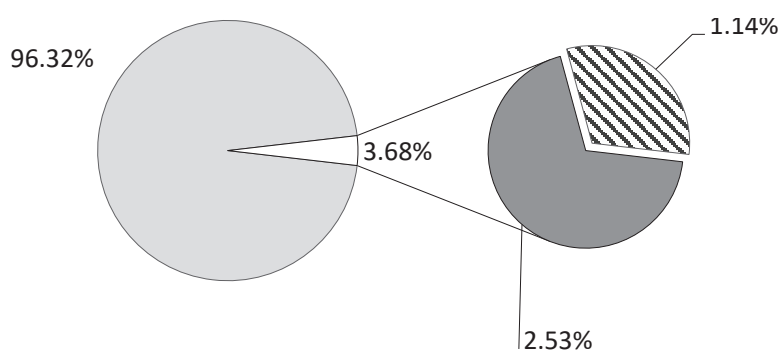

$\square$ Patients diagnosed with acute otitis media who did not require hospitalization

$\square$ Patients diagnosed with acute otitis media who required hospitalization

s Patients diagnosed with mastoiditis

Figure 1. The percentage distribution of patients who reported to the emergency room of PUMS pediatric hospital

Among the hospitalized patients, 18 developed mastoiditis - a complication of AOM. Based on the age of the whole analyzed group of patients, children up to the age of 4 were the group which most frequently reported to the hospital ER because of acute otitis media (Figure 2). The frequency of patients reporting with this diagnosis decreased with increasing age of the children.

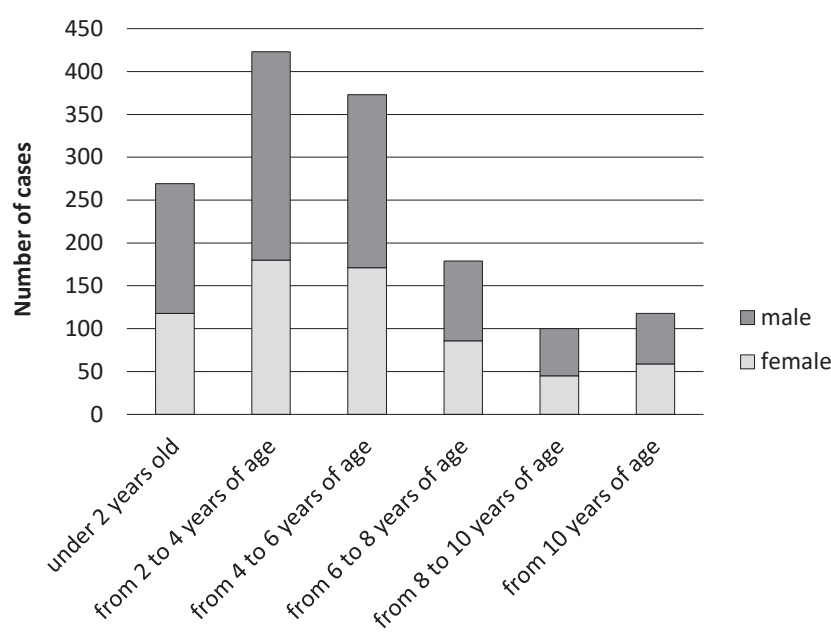

Figure 2. Numbers of patients reported to the ER of PUMS pediatric hospital grouped by their age and gender

Hospitalized patients who presented a higher incidence of complications in the form of mastoiditis were mainly children up to 4 years of age (Figure 3). In the time period from January 2017 to April 2018, there were no cases of mastoiditis in children over 8 years of age.

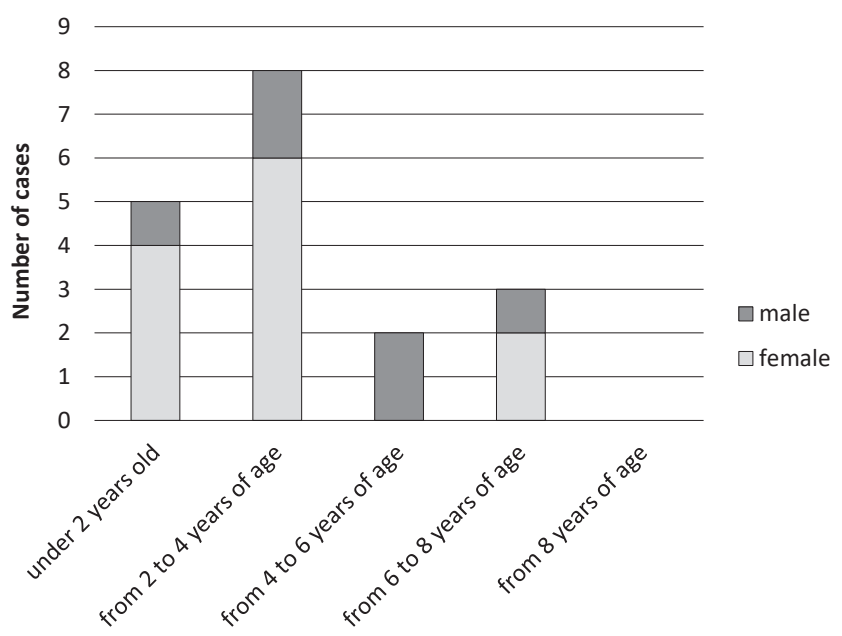

Figure 3. Occurrence of mastoiditis at PUMS pediatric hospital grouped by their age and gender

Chi-squared test was performed comparing the age and sex of the group of patients treated in the ER with the second group of patients hospitalized for mastoiditis. Test results showed that there is no significant difference between two groups of patients in this regard ( $p=0.68$ and $p=0.20$, respectively). Mann-Whitney $U$ test, which was also applied to this analysis, demonstrated there is no significant difference between the groups ( $p=0.20$ and $p=0.18$, respectively).

Patients with mastoiditis hospitalized at the Pediatric Otolaryngology Department underwent inflammatory markers analyses. The results of the laboratory tests are characterized by a large range of values, with CRP values ranging from 0.44 $\mathrm{mg} / \mathrm{dL}$ to $17.82 \mathrm{mg} / \mathrm{dL}$ (median value: $10.87 \mathrm{mg} / \mathrm{dL}$ ) and $\mathrm{WBC}$ values from $7.26 \times 10^{3} / \mu \mathrm{L}$ to $25.99 \times 10^{3} / \mu \mathrm{L}$ (median value: $16.67 \times 10^{3} / \mu \mathrm{L}$ ) (Table 1). Statistical analysis measuring the dependence of the level of inflammatory markers in relation to the used treatment and length of hospitalization could not be performed for the group of children with mastoiditis, as it was 
a very small population and the large spread of results made it impossible to carry out a statistical analysis with a reliable confidence factor $\alpha$. Further amounts of data are being collected to increase the population size and possibly enable it to find any correlations.

In the study, Streptococcus pneumoniae was the most frequently occurring pathogen in the secretion fluid collected from the middle ear of patients. Pathogens such as Pseudomonas aeruginosa, Corynebacterium sp., Streptococcus pyogenes and Staphylococcus sp. also appeared in the analyzed material. Part of the collected secretion was, according to microbiology as- sessment, a sterile purulent secretion. Such results may occur if the secretion collection was performed after the implementation of the antibiotic therapy. The basic treatment included intravenous antibiotic therapy. The most commonly utilized antibiotic was $3^{\text {rd }}$ generation cephalosporin administered intravenously (Ceftriaxone, Cefotaxime), but drugs such as Amoxicillin with clavulanic acid, Cefuroxime, Metronidazole and Clindamycin or a combination of 2 or more of the above-mentioned antibiotics, were also administered. Additionally, Ciprofloxacin was sometimes added in the form of a topical formulation to the auditory canal.

\begin{tabular}{|c|c|c|c|c|c|c|c|c|}
\hline No. & Age (y) & Side & Gender & $\begin{array}{l}\text { CRP } \\
\text { (mg/dL) }\end{array}$ & $\begin{array}{l}\text { WBC } \\
(10 \times 3 / \mu L)\end{array}$ & Pathogen & Antibiotic & Applied treatment \\
\hline 1 & 0.8 & L & $\mathrm{F}$ & 2.71 & 19.52 & Streptococcus pneumoniae & $\begin{array}{l}\text { Ceftriaxone iv } \\
\text { Metronidazole iv }\end{array}$ & $\begin{array}{l}\text { AM and myringotomy } \\
\text { with VTP }\end{array}$ \\
\hline 2 & 1.2 & L & $\mathrm{F}$ & 15.69 & 25.99 & Streptococcus pneumoniae & Ceftriaxone iv & $\begin{array}{l}\text { AM and myringotomy } \\
\text { with VTP }\end{array}$ \\
\hline 3 & 1.2 & L & M & 10.95 & 20.54 & Staphylococcus sp. & $\begin{array}{l}\text { Cefuroxime iv } \\
\text { Clindamycin iv } \\
\text { Ciprofloxacin (topical) }\end{array}$ & $\begin{array}{l}\text { AM and myringotomy } \\
\text { with VTP }\end{array}$ \\
\hline 4 & 1.7 & $R$ & $F$ & 12.03 & 13.06 & Streptococcus pneumoniae & Ceftriaxone iv & $\begin{array}{l}\text { Myringotomy with } \\
\text { VTP }\end{array}$ \\
\hline 5 & 1.8 & L & $\mathrm{F}$ & 0.44 & 13.79 & material was not taken & $\begin{array}{l}\text { Cefuroxime iv } \\
\text { Cefotaxime iv } \\
\text { Clindamycin iv }\end{array}$ & $\begin{array}{l}\text { AM and myringotomy } \\
\text { with VTP }\end{array}$ \\
\hline 6 & 2.3 & L & $\mathrm{F}$ & 15.41 & 10.19 & sterile & $\begin{array}{l}\text { Cefuroxime iv } \\
\text { Metronidazole iv } \\
\text { Ciprofloxacin (topical) }\end{array}$ & $\begin{array}{l}\text { AM and myringotomy } \\
\text { with VTP }\end{array}$ \\
\hline 7 & 2.8 & L & $F$ & 6.02 & 17.29 & Streptococcus pneumoniae & $\begin{array}{l}\text { Amoxicillin with clavu- } \\
\text { lanic acid iv }\end{array}$ & $\begin{array}{l}\text { AM and myringotomy } \\
\text { with VTP }\end{array}$ \\
\hline 8 & 3.1 & L & $\mathrm{F}$ & 2.53 & 16.05 & sterile & $\begin{array}{l}\text { Ceftriaxone iv } \\
\text { Metronidazole iv } \\
\text { Amoxicillin with clavu- } \\
\text { lanic acid iv } \\
\text { Ciprofloxacin (topical) }\end{array}$ & $\begin{array}{l}\text { Myringotomy with } \\
\text { VTP }\end{array}$ \\
\hline 9 & 3.2 & L & $F$ & 4.79 & 14.17 & $\begin{array}{l}\text { Pseudomonas aeruginosa, } \\
\text { Corynebacterium sp. }\end{array}$ & $\begin{array}{l}\text { Amoxicillin with clavu- } \\
\text { lanic acid iv } \\
\text { Ciprofloxacin (topical) }\end{array}$ & $\begin{array}{l}\text { Myringotomy with } \\
\text { VTP }\end{array}$ \\
\hline 10 & 3.4 & L & $\mathrm{F}$ & 16.88 & 14.69 & $\begin{array}{l}\text { Streptococcus pneumoniae, } \\
\text { Staphylococcus sp. }\end{array}$ & $\begin{array}{l}\text { Ceftriaxone iv } \\
\text { Clindamycin iv }\end{array}$ & $\begin{array}{l}\text { AM and myringotomy } \\
\text { with VTP }\end{array}$ \\
\hline 11 & 3.4 & $\mathrm{R}$ & M & 17.74 & 20.42 & $\begin{array}{l}\text { Streptococcus pneumoniae, } \\
\text { Staphylococcus sp. }\end{array}$ & Ceftriaxone iv & $\begin{array}{l}\text { AM and myringotomy } \\
\text { with VTP }\end{array}$ \\
\hline 12 & 3.8 & L & M & 10.99 & 21.01 & Staphylococcus sp. & Ceftriaxone iv & $\begin{array}{l}\text { AM and myringotomy } \\
\text { with VTP }\end{array}$ \\
\hline 13 & 3.8 & $\mathrm{R}$ & $F$ & 0.44 & 7.26 & sterile & $\begin{array}{l}\text { Ceftriaxone iv } \\
\text { Amoxicillin with clavu- } \\
\text { lanic acid iv }\end{array}$ & $\begin{array}{l}\text { AM and myringotomy } \\
\text { with VTP }\end{array}$ \\
\hline 14 & 4.9 & $R$ & $M$ & 17.82 & 18.48 & sterile & $\begin{array}{l}\text { Amoxicillin with clavu- } \\
\text { lanic acid iv }\end{array}$ & $\begin{array}{l}\text { AM and myringotomy } \\
\text { with VTP }\end{array}$ \\
\hline 15 & 6.3 & $R$ & M & 15.93 & 24.95 & $\begin{array}{l}\text { Streptococcus pyogenes, } \\
\text { Staphylococcus sp. }\end{array}$ & Ceftriaxone iv & Myringotomy \\
\hline 16 & 6.3 & L & $\mathrm{F}$ & 2.35 & 9.6 & sterile & $\begin{array}{l}\text { Ceftriaxone iv } \\
\text { Clindamycin iv }\end{array}$ & $\begin{array}{l}\text { AM and myringotomy } \\
\text { with VTP }\end{array}$ \\
\hline 17 & 6.5 & L & $F$ & 10.79 & 15.16 & Streptococcus pneumoniae & $\begin{array}{l}\text { Ceftriaxone iv } \\
\text { Clindamycin iv }\end{array}$ & $\begin{array}{l}\text { AM and myringotomy } \\
\text { with VTP }\end{array}$ \\
\hline 18 & 6.8 & $\mathrm{R}$ & M & 7.5 & 17.35 & Pseudomonas aeruginosa & $\begin{array}{l}\text { Ceftriaxone iv } \\
\text { Ciprofloxacin (topical) }\end{array}$ & $\begin{array}{l}\text { AM and myringotomy } \\
\text { with VTP }\end{array}$ \\
\hline
\end{tabular}

Reference ranges - CRP: $\leq 0.5 \mathrm{mg} / \mathrm{dL}, \mathrm{WBC}: 4.5 \times 10 \times 3 / \mu \mathrm{L}-13.0 \times 10 \times 3 / \mu \mathrm{L}$ Shortcuts $-\mathrm{L}$ : left, R: right, F: female, M: male. 
The primary surgical treatment of mastoiditis is myringotomy with or without a ventilation tube placement (VTP). Paracentesis improves the general condition of the child by draining the space of the middle ear affected by inflammation and thus allowing the outflow of accumulated fluid. This procedure in combination with VTP enables extended ventilation of the middle ear for several months. Paracentesis with the ventilation tube placement was performed in the vast majority of the children hospitalized with complication of AOM (94.44\%). In the case of only one child, the therapeutic procedure was limited to the use of intravenous antibiotics therapy with myringotomy without ventilation tube placement. The general condition improved in some patients after the use of intravenous antibiotic therapy, however, 14 children required advanced surgical treatment - an antromastroidectomy (AM). The length of hospitalization of patients with a complication of otitis media ranged from 6 to 13 days (median 10). Each case of mastoiditis required hospitalization.

\section{Discussion}

The most common, but still rarely occurring complication of AOM is mastoiditis $[7,8]$. The cause of mastoiditis is the spread of the inflammatory process in the temporal bone. Inflammation includes the tympanic cavity and air cells of the mastoid process because these spaces have a connection with each other [2, 3]. In some cases, bone destruction or the formation of inflammatory granules may also occur. Mastoiditis is usually manifested by symptoms of skin inflammation over the mastoid process (redness and/or swelling in the area behind the earlobe) and in the case of the formation of subperiosteal abscess, a protruding earlobe (Table 2). Symptoms of mastoiditis usually appear during or after the infection of the middle ear, so the observed symptoms may be earache and fever. Signs observed upon the otoscopic examination may include a convex tympanic membrane, perforation with leakage of purulent secretion fluid and, in rare cases, collapse of the upper and posterior wall of the external auditory canal $[3,4]$.

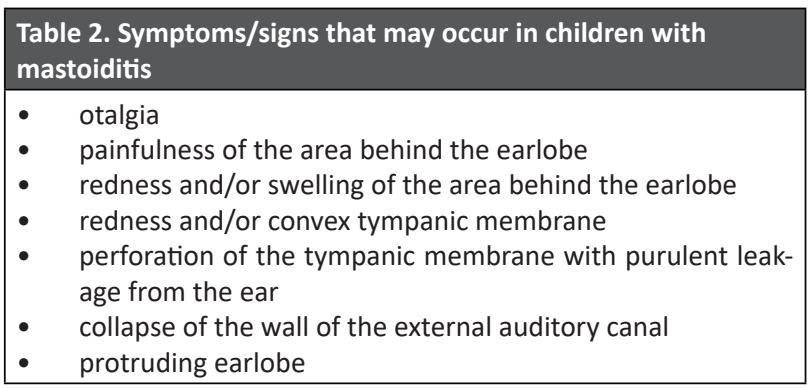

Factors that significantly contribute to the effectiveness of prevention and treatment of acute otitis media and mastoiditis include an increase in the availability of diagnostic tests, rationally applied antibiotic therapy, as well as the development of surgical techniques in the field of otosurgery. Computed tomography (CT) is an imaging method recommended in order to evaluate the state of inflammation in the mastoid. The pathological filling of pneumatic spaces of the mastoid and tympanic cavity can be observed in computed tomography imaging (Figure 4,5).

In the advanced form of the disease, destruction of the bone and ossicles may be seen, as well as a fistula between the mastoid cavity and the subcutaneous tissue surrounding the ear mantle (in the case of the formation of a subperiosteal abscess) [8]. Currently, there is a tendency to perform imaging examinations limited to the (a) cases of patients suffering from neurological symptoms, (b) in suspicion of intracranial complications or (c) in the absence of improvement within 48 to 72 hours of treatment [6].

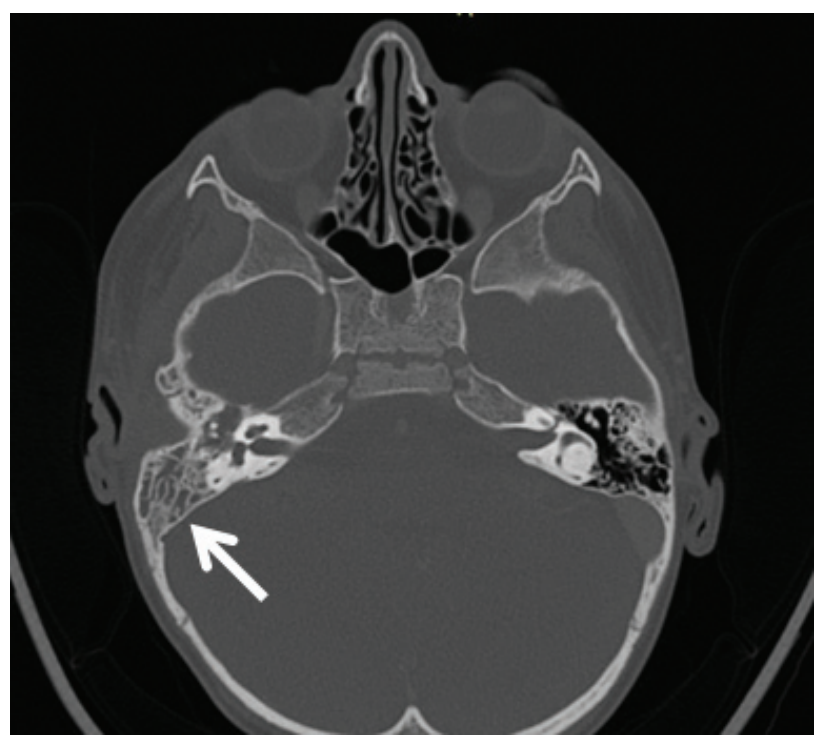

Figure 4. CT imaging of the mastoiditis - axial (own material)

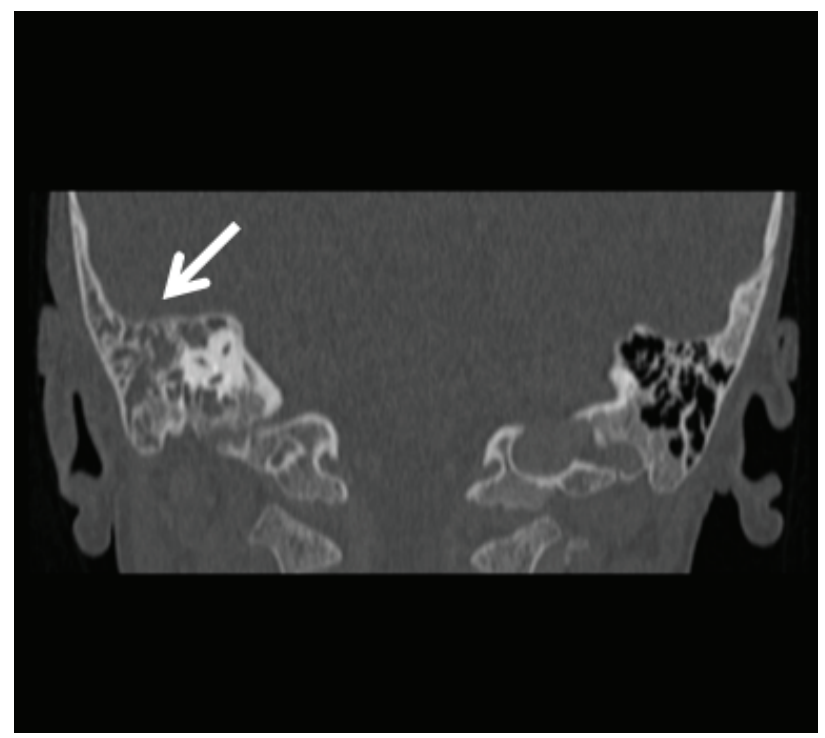

Figure 5. CT imaging of mastoiditis - frontal (own material)

Treatment of mastoiditis does not require antromasteidectomy in all cases. This is the final procedure for patients whose condition is not improving. In some patients, paracentesis combined with antibiotic therapy results in satisfactory outcome [5-7].

\section{Conclusions}

The number of cases of inflammation of the middle ear requiring hospitalization in Pediatric Otolaryngology Department Poznan University of Medical Sciences is minimal. Acute otitis media may be successfully treated in outpatient clinic by family physicians and pediatricians. In cases of suspicion of mastoiditis, the patient is required to be immediately directed to the otolaryngologist. In the practice of the family doctor, early detection of the potential complication is crucial.

Source of funding: This work was funded from the authors' own resources.

Conflicts of interest: The authors declare no conflicts of interest. 


\section{References}

1. Topczewska-Cabanek A, Gomułka B, Nitsch-Osuch A, et al. Analiza przyczyn hospitalizacji dzieci w oddziale otolaryngologicznym wybranego szpitala w Warszawie. Fam Med Prim Care Rev 2013; 15(2): 188-191 (in Polish).

2. Mierzwiński J, Tyra J, Haber K, et al. Pediatric recurrent acute mastoiditis: risk factors and insights into pathogenesis. Int J Pediatr Otorhinolaryngol 2018; 111: 142-148.

3. Kynion R. Mastoiditis. Pediatr Rev 2018; 39(5): 267-269.

4. Wilson E, Jenner L, Paul SP. Mastoiditis: on the rise again? Br J Nurs 2017; 26(10): 542, doi: 10.12968/bjon.2017.26.10.542.

5. Ghadersohi S, Young NM, Smith-Bronstein V, et al. Management of acute complicated mastoiditis at an urban, tertiary care pediatric hospital. Laryngoscope 2017; 127(10): 2321-2327.

6. Chesney J, Black A, Choo D. What is the best practice for acute mastoiditis in children? Laryngoscope 2014; 124(5): $1057-1058$.

7. Loh R, Phua M, Shaw CL. Management of paediatric acute mastoiditis: systematic review. J Laryngol Otol 2018; 132(2): 96-104.

8. Carmel E, Curotta JH, Cheng AT. Prognostic effect of pre- and post-admission antibiotic treatment in paediatric acute mastoiditis. J Laryngol Otol 2017; 131(1): 12-17.

Tables: 2

Figures: 5

References: 8

Received: 15.05.2018

Reviewed: 28.05.2018

Accepted: 21.07.2018

Address for correspondence:

Agata Kałużna-Młynarczyk, MD

Klinika Otolaryngologii Dziecięcej UM

ul. Szpitalna 27/33

60-572 Poznań

Polska

Tel.: +48 61 849-15-90

E-mail: mlynarczyk.agataa@gmail.com 